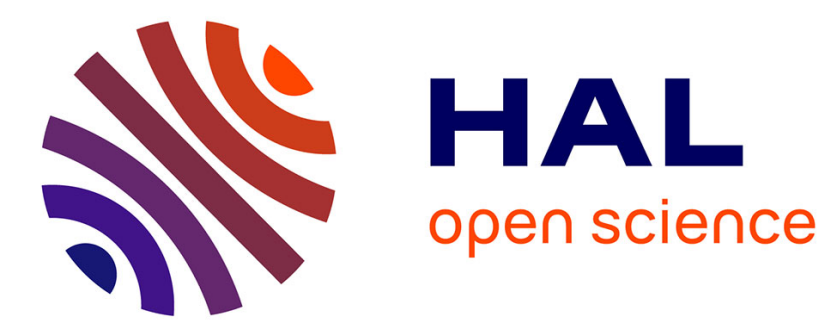

\title{
Topological and Steric Constraints to Stabilize Heteroleptic Copper(I) Complexes Combining Phenanthroline Ligands and Phosphines
}

\author{
Michel Holler, Béatrice Delavaux-nicot, Jean-françois Nierengarten
}

\section{- To cite this version:}

Michel Holler, Béatrice Delavaux-nicot, Jean-françois Nierengarten. Topological and Steric Constraints to Stabilize Heteroleptic Copper(I) Complexes Combining Phenanthroline Ligands and Phosphines. Chemistry - A European Journal, 2019, 25 (18), pp.4543-4550. 10.1002/chem.201805671. hal-02133959

\section{HAL Id: hal-02133959 \\ https://hal.science/hal-02133959}

Submitted on 26 Oct 2020

HAL is a multi-disciplinary open access archive for the deposit and dissemination of scientific research documents, whether they are published or not. The documents may come from teaching and research institutions in France or abroad, or from public or private research centers.
L'archive ouverte pluridisciplinaire HAL, est destinée au dépôt et à la diffusion de documents scientifiques de niveau recherche, publiés ou non, émanant des établissements d'enseignement et de recherche français ou étrangers, des laboratoires publics ou privés. 
Topological and steric constraints to stabilize heteroleptic copper(I) complexes combining phenanthroline ligands and phosphines

Michel Holler, ${ }^{\left[{ }^{[a]}\right.}$ Béatrice Delavaux-Nicot ${ }^{*[b]}$ and Jean-François Nierengarten, ${ }^{*[a]}$

Dedicated to Prof. Jean-Pierre Sauvage on the occasion of his $75^{\text {th }}$ birthday

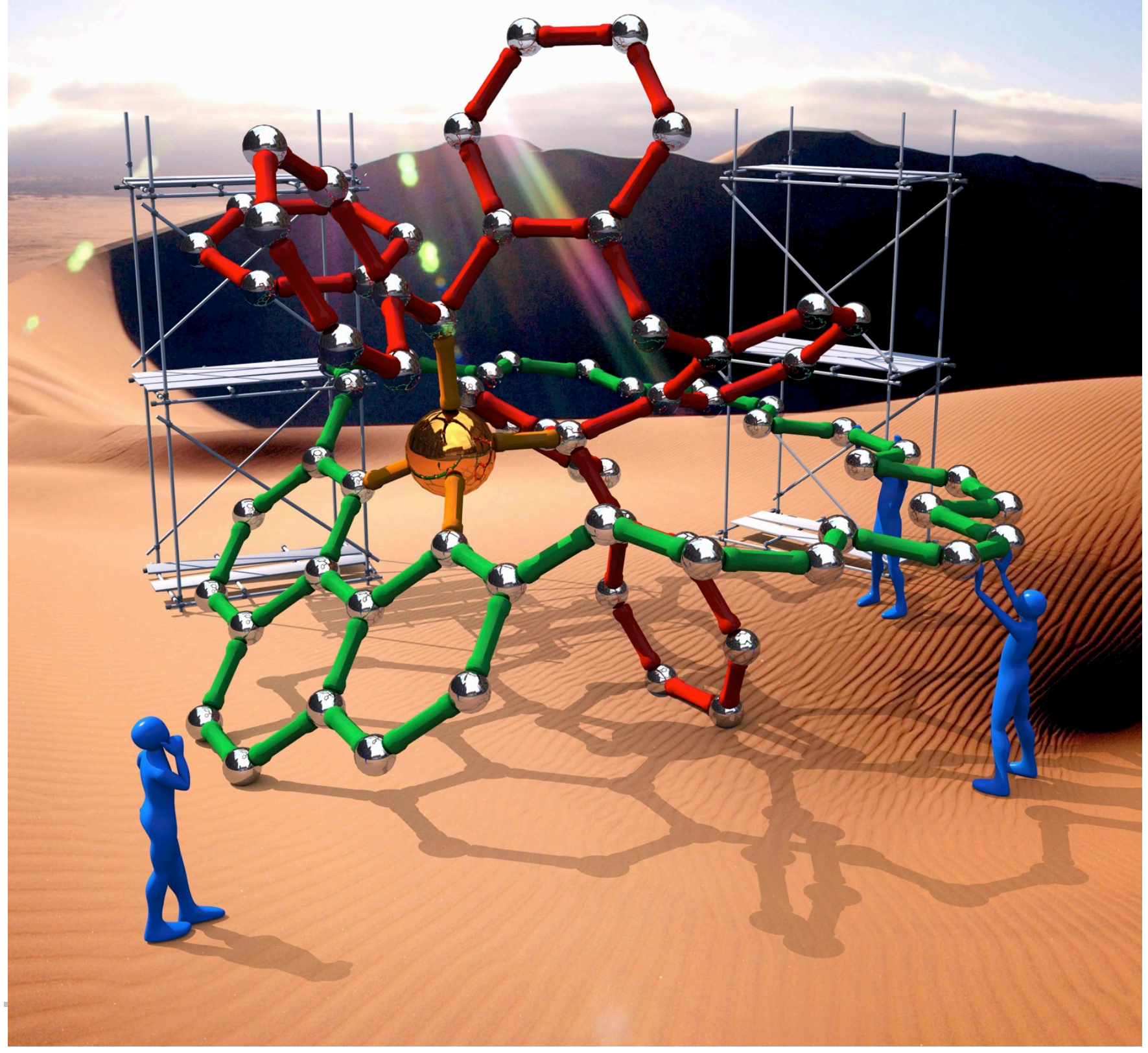


Abstract: Heteroleptic copper(I) complexes combining phenanthroline derivatives (NN) and chelating bis-phosphine ligands (PP) are an important class of luminescent materials for various applications. While thermodynamically stable, $[\mathrm{Cu}(\mathrm{NN})(\mathrm{PP})]^{+}$derivatives are also kinetically unstable. As a result, a dynamic ligand exchange reaction is often observed in solution leading to a dynamic mixture of heteroleptic and homoleptic complexes. In order to prevent the formation of the homoleptic species, macrocyclic phenanthroline ligands have been used for the preparation of $[\mathrm{Cu}(\mathrm{NN})(\mathrm{PP})]^{+}$pseudorotaxanes. The topological constraint resulting from the macrocyclic structure of the NN ligand drives the thermodynamic equilibrium toward the exclusive formation of the heteroleptic complex as long as the macrocycle is large and flexible enough to allow the threading of the PP ligand. In contrast, when the threading is prevented by steric constraints, unprecedented copper(I) complexes with a trigonal coordination geometry are obtained. These results are summarized in the present concept article.

\section{Introduction}

In recent years, there has been a revival of interest in the field of luminescent copper $(\mathrm{I})$ complexes. ${ }^{[1-4]}$ On one hand, such compounds are perfectly suited for the preparation of light emitting devices ${ }^{[2]}$ and dye sensitized solar cells. ${ }^{[3]}$ When compared to the heavy metal complexes typically used in these technologies, coordination compounds prepared from copper represent an interesting alternative with less concerns about toxicity and environmental impact. ${ }^{[1-4]}$ On the other hand, the recent interest in photochemistry by organic chemists has also contributed to popularize copper $(I)$ photosensitizers. ${ }^{[4]}$ In this context, heteroleptic copper(I) complexes combining diimine aromatic ligands (NN) such as phenanthroline derivatives and bis-phosphine (PP) ligands have focused particular attention..$^{[5-11]}$ Analogous systems prepared from NN ligands and phosphines $\left(\mathrm{PR}_{3}\right)$ have been widely explored in relation to photo-induced electron transfer long ago. ${ }^{[12-13]}$ The coordination of the different ligands around the copper $(\mathrm{I})$ cation is however particularly difficult to control owing to the kinetic instability of $\left[\mathrm{Cu}(\mathrm{NN})\left(\mathrm{PR}_{3}\right)_{2}\right]^{+}$derivatives leading to ligand dissociation in solution. The use of chelating bis-phosphine ligands has been introduced by McMillin and co-workers in 2002. ${ }^{[5]}$ Importantly,

[a] Dr. M. Holler, Dr. J.-F. Nierengarten

Laboratoire de Chimie des Matériaux Moléculaires

Université de Strasbourg et CNRS (LIMA - UMR 7042)

Ecole Européenne de Chimie, Polymères et Matériaux (ECPM)

25 rue Becquerel, 67087 Strasbourg Cedex 2, France

E-mail: nierengarten@unistra.fr

[b] Dr. B. Delavaux-Nicot

Laboratoire de Chimie de Coordination du CNRS (UPR 8241)

Université de Toulouse (UPS, INPT), 205 Route de Narbonne,

31077 Toulouse Cedex 04, France

E-mail: beatrice.delavaux-nicot@lcc-toulouse.fr the stability of the resulting $[\mathrm{Cu}(\mathrm{NN})(\mathrm{PP})]^{+}$derivatives is significantly improved when compared to analogous compounds prepared from $\mathrm{PR}_{3}$ ligands. Moreover, some members of the $[\mathrm{Cu}(\mathrm{NN})(\mathrm{PP})]^{+}$family have shown remarkably high emission quantum yields from their long-lived metal-to-ligand charge transfer (MLCT) exited states. ${ }^{[5-6]}$ These initial observations are at the origin of significant research efforts related to the photophysical properties of $[\mathrm{Cu}(\mathrm{NN})(\mathrm{PP})]^{+}$derivatives and their applications $^{[7-11]}$ As part of this research, we have carried out detailed investigations on the dynamic coordination behavior of $\mathrm{NN}$ and PP ligands around the copper(I) cation. ${ }^{[14]}$ A deep understanding of the structural parameters influencing the stability of $[\mathrm{Cu}(\mathrm{NN})(\mathrm{PP})]^{+}$derivatives is indeed essential for the proper design of stable luminescent materials. In solution, the control of the heteroleptic coordination scenario is difficult and an equilibrium between the heteroleptic - $[\mathrm{Cu}(\mathrm{NN})(\mathrm{PP})]^{+}-$and the homoleptic - $\left[\mathrm{Cu}(\mathrm{NN})_{2}\right]^{+}$and $\left[\mathrm{Cu}(\mathrm{PP})_{2}\right]^{+}$- complexes is often observed. In order to drive the thermodynamic equilibrium toward the desired heteroleptic complex, we have applied a synthetic strategy based on topological constrains by using macrocyclic phenanthroline derivatives. ${ }^{[15-18]}$ Stable heteroleptic copper(I)-complexed pseudo-rotaxanes have been thus obtained when the macrocyle is large and flexible enough to allow the threading of the diphenylphosphino groups of the PP ligands. ${ }^{[15-17]}$ In contrast, the complexation scenario is completely different when the macrocyclic NN ligand prevents the threading of the PP ligand. In this case, the additional steric constraint drives the coordination equilibrium toward the formation of unprecedented copper(I) complexes with a trigonal coordination geometry. ${ }^{[18]}$ These results are summarized in the present concept article with special emphasis on the coordination chemistry aspects.

\section{Stability of heteroleptic [Cu(NN)(PP) $]^{+}$ complexes}

In order to understand the structural parameters influencing the stability of $[\mathrm{Cu}(\mathrm{NN})(\mathrm{PP})]^{+}$derivatives, a series of chelating PP ligands (dppe, dpp, dppb and POP) have been combined with various phenanthroline derivatives. ${ }^{[14]}$ The preparation of the complexes from 2,9-unsubstituted-1,10-phenanthroline ligands has been investigated first (Scheme 1). Treatment of phen or Bphen (1 equiv.) with the appropriate PP ligand (dppe, dppp, dppb or POP, 1 equiv.) and $\left[\mathrm{Cu}\left(\mathrm{CH}_{3} \mathrm{CN}\right)_{4}\right] \mathrm{BF}_{4}$ (1 equiv.) provided the corresponding $[\mathrm{Cu}(\mathrm{NN})(\mathrm{PP})] \mathrm{BF}_{4}$ derivatives. ${ }^{1} \mathrm{H}$ and ${ }^{31} \mathrm{P}$ NMR analysis of the crude reaction mixtures revealed the formation of a single complex in all the cases and the expected heteroleptic complexes have been isolated in a pure form by recrystallization. Importantly, detailed ${ }^{1} \mathrm{H}$ and ${ }^{31} \mathrm{P}$ NMR investigations revealed that all the $[\mathrm{Cu}($ phen $)(\mathrm{PP})] \mathrm{BF}_{4}$ and $[\mathrm{Cu}(\mathrm{Bphen})(\mathrm{PP})] \mathrm{BF}_{4}$ derivatives are stable compounds in dichloromethane or acetonitrile solutions and no traces of homoleptic complexes could be detected. 


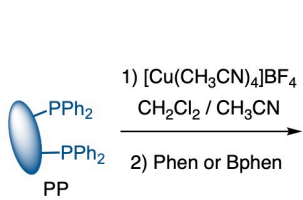

$\mathrm{PP}=\mathrm{dppe}, \mathrm{dppp}, \mathrm{dppb}$ or $\mathrm{POP}$

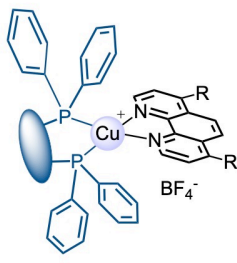

$\mathrm{R}=\mathrm{H}[\mathrm{Cu}($ phen $)(\mathrm{PP})] \mathrm{BF}_{4}$ $\mathrm{R}=\mathrm{Ph}[\mathrm{Cu}(\mathrm{Bphen})(\mathrm{PP})] \mathrm{BF}_{4}$

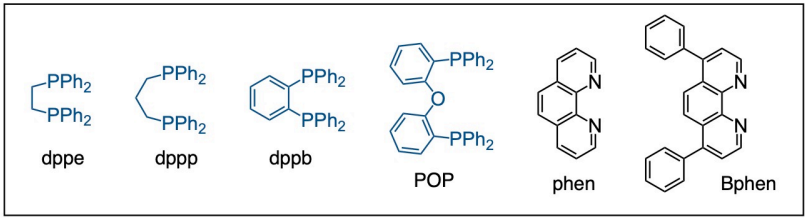

Scheme 1. Preparation of $[\mathrm{Cu}(\mathrm{NN})(\mathrm{PP})]^{+}$complexes. Inset: structure of the $\mathrm{NN}$ and PP ligands.

In a second series of experiments, 2,9-substitutedphenanthroline derivatives (dmp, dpep or dpp) have been used as $\mathrm{NN}$ ligands to prepare the corresponding $[\mathrm{Cu}(\mathrm{NN})(\mathrm{PP})]^{+}$ derivatives (Figure 1). Treatment of dmp, dpep or dpp with an equimolar mixture of the appropriate $\mathrm{PP}$ ligand and $\left[\mathrm{Cu}\left(\mathrm{CH}_{3} \mathrm{CN}\right)_{4}\right] \mathrm{BF}_{4}$ gave a dynamic mixture of different complexes, namely $[\mathrm{Cu}(\mathrm{NN})(\mathrm{PP})] \mathrm{BF}_{4}, \quad\left[\mathrm{Cu}(\mathrm{NN})_{2}\right] \mathrm{BF}_{4}$ and $\left[\mathrm{Cu}(\mathrm{PP})_{2}\right] \mathrm{BF}_{4}$ (Figure 1). ${ }^{[14]}$ The percentage of $\left[\mathrm{Cu}(\mathrm{NN})\left(\mathrm{PP}^{2}\right] \mathrm{BF}_{4}\right.$ is indicated in Figure $1 \mathrm{~B}$ for all the ligands combinations. All the dmpcontaining heteroleptic complexes have been obtained pure by recrystallization. ${ }^{[14]}[\mathrm{Cu}(\mathrm{dmp})(\mathrm{dppe})] \mathrm{BF}_{4}, \quad[\mathrm{Cu}(\mathrm{dmp})(\mathrm{dppp})] \mathrm{BF}_{4}$, and $[\mathrm{Cu}(\mathrm{dmp})(\mathrm{dppb})] \mathrm{BF}_{4}$ are perfectly stable in the solid state. However, dynamic ligand exchange is systematically observed as soon as the compounds are dissolved leading to an equilibration between the heteroleptic and the homoleptic complexes. In a coordinating solvent such as $\mathrm{CH}_{3} \mathrm{CN}$, the equilibrium is reached in less than a minute and the final heteroleptic/homoleptic ratio is the same as the one observed for the corresponding crude mixture. In contrast, in a noncoordinating solvent such as $\mathrm{CH}_{2} \mathrm{Cl}_{2}$, the ligand exchange reaction is rather slow and a few hours are needed to reach the equilibrium. It is therefore possible to investigate the photophysical properties of such heteroleptic complexes out of equilibrium by using freshly prepared $\mathrm{CH}_{2} \mathrm{Cl}_{2}$ solutions. ${ }^{[19]}$ In the case of dppe, dppp and dppb, the homoleptic $\left[\mathrm{Cu}(\mathrm{PP})_{2}\right] \mathrm{BF}_{4}$ complexes are all tetracoordinated (Figure 1D). ${ }^{[14,20]}$ As a result, all the ligands and metal binding sites are utilized to generate coordinatively saturated complexes whatever the $[\mathrm{Cu}(\mathrm{NN})(\mathrm{PP})] \mathrm{BF}_{4} /\left[\mathrm{Cu}(\mathrm{NN})_{2}\right] \mathrm{BF}_{4} /\left[\mathrm{Cu}(\mathrm{PP})_{2}\right] \mathrm{BF}_{4}$ ratio in solution. The dynamic equilibrium is therefore only governed by the relative thermodynamic stability of the different possible complexes. On one hand, the exceptionally high thermodynamic stability of $\left[\mathrm{Cu}(\mathrm{NN})_{2}\right] \mathrm{BF}_{4}$ derivatives obtained from 2,9substituted-phenanthrolines $(\log \beta=10-12)^{[21]}$ tends to drive the equilibrium toward the formation of the homoleptic complexes. On the other hand, differences in the P-Cu-P chelate bite-angle modulates the negative steric effects leading to the destabilization of $[\mathrm{Cu}(\mathrm{dmp})(\mathrm{PP})]^{+}$or $[\mathrm{Cu}(\mathrm{dpep})(\mathrm{PP})]^{+}$, thus explaining the difference in behavior for the various PP ligands. On the other hand, the thermodynamic equilibrium is displaced toward the homoleptic complexes when going from dmp to dpep. By increasing the size of the 2,9-substituents on the phenanthroline subunit, negative steric effects become more important and the heteroleptic complexes are further destabilized. Ultimately, the formation of heteroleptic complexes is almost totally prevented when the NN ligand is substituted with large groups. This is the case of dpp for which only homoleptic complexes are obtained whatever the PP ligands.

(A)

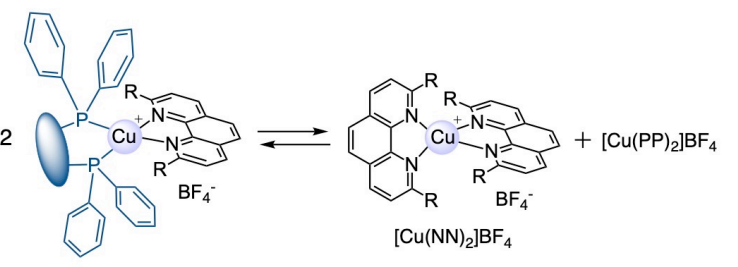

$[\mathrm{Cu}(\mathrm{NN})(\mathrm{PP})] \mathrm{BF}_{4}$
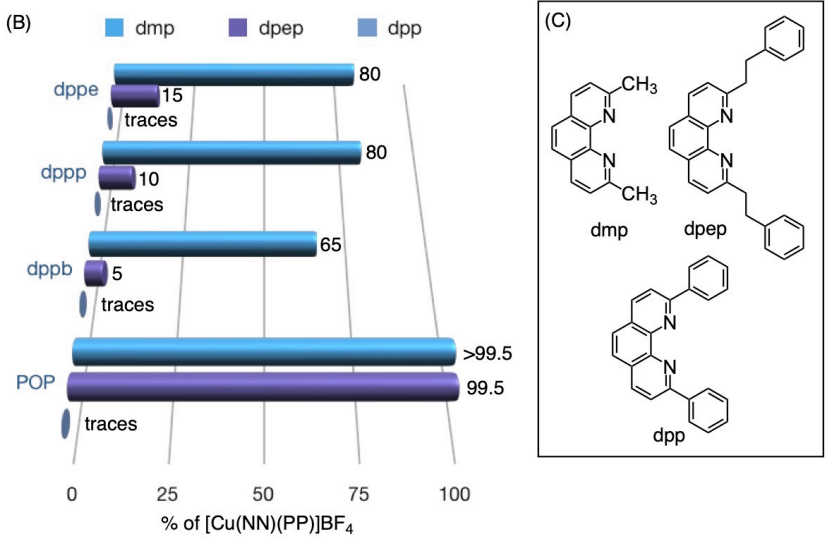

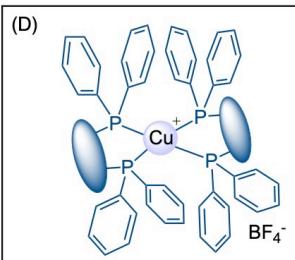

$\left[\mathrm{Cu}(\mathrm{PP})_{2}\right] \mathrm{BF}_{4}$ $\mathrm{PP}=$ dppe, dppp or dppb

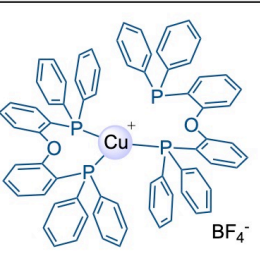

$\left[\mathrm{Cu}(\mathrm{POP})_{2}\right] \mathrm{BF}_{4}$
Figure 1. (A) Dynamic ligand exchange observed in solution, the relative proportion of the heteroleptic - $[\mathrm{Cu}(\mathrm{NN})(\mathrm{PP})]^{+}$- and the homoleptic $\left[\mathrm{Cu}(\mathrm{NN})_{2}\right]^{+}$and $\left[\mathrm{Cu}(\mathrm{PP})_{2}\right]^{+}$- complexes is highly dependant on the nature of the ligands. (B) Proportion of heteroleptic complex at the thermodynamic equilibrium in $\mathrm{CH}_{2} \mathrm{Cl}_{2}$ at $25^{\circ} \mathrm{C}$, identical values are observed in $\mathrm{CH}_{3} \mathrm{CN}$ at $25^{\circ} \mathrm{C}$. (C) Structure of the 2,9-substituted phenanthroline ligands. (D) Structure of the $\left[\mathrm{Cu}(\mathrm{PP})_{2}\right]^{+}$derivatives.

For $[\mathrm{Cu}(\mathrm{dmp})(\mathrm{POP})] \mathrm{BF}_{4}$, and $[\mathrm{Cu}(\mathrm{dpep})(\mathrm{POP})] \mathrm{BF}_{4}$, ligand exchange reactions took place to a minor extent and only traces of the homoleptic species could be detected in solution. The remarkable stability of the POP-containing heteroleptic complexes results, at least in part, from the favorable orientation 
of the diphenylphosphino subunits limiting steric hindrance. ${ }^{[6,14]}$ The thermodynamic equilibrium is also influenced by the peculiar structure of $\left[\mathrm{Cu}(\mathrm{POP})_{2}\right]^{+}$. The copper(I) cation is actually too small to accommodate two POP ligands in a tetrahedral coordination geometry. ${ }^{[14,22]}$ Only one POP subunit is chelating the metal, while the second one is acting as a monodentate ligand (Figure 2D). With its trigonal coordination geometry, $\left[\mathrm{Cu}(\mathrm{POP})_{2}\right]^{+}$is a coordinatively frustrated metal-ligand assembly. As a result, $\left[\mathrm{Cu}(\mathrm{POP})_{2}\right]^{+}$substantially destabilizes the homoleptic coordination scenario and its unsaturated copper(I) cation counterbalances the exceptionally high thermodynamic stability of $\left[\mathrm{Cu}(\mathrm{NN})_{2}\right]^{+}$. In other words, the reduced thermodynamic stability of $\left[\mathrm{Cu}(\mathrm{POP})_{2}\right]^{+}$contributes to displace the equilibrium toward the formation of $[\mathrm{Cu}(\mathrm{NN})(\mathrm{POP})]^{+}$.

This detailed investigation revealed that $[\mathrm{Cu}(\mathrm{NN})(\mathrm{PP})]^{+}$ complexes are stable in solution as long as they incorporate 2,9unsubstituted phenanthroline ligands. By contrast, heteroleptic complexes obtained from 2,9-substituted phenanthrolines are only stable in the solid state but a dynamic ligand exchange reaction is systematically observed in solution. The presence of bulky substituents at the 2 and 9 positions of the phenanthroline subunit is however critical for the photophysical properties of $[\mathrm{Cu}(\mathrm{NN})(\mathrm{PP})]^{+}$derivatives. ${ }^{[4 c, 7]}$ This is clearly illustrated by the emission quantum yields $(\Phi)$ determined in deaerated $\mathrm{CH}_{2} \mathrm{Cl}_{2}$ solutions at $25^{\circ} \mathrm{C}$ for $[\mathrm{Cu}(\mathrm{NN})(\mathrm{POP})]^{+}$derivatives $(\Phi=0.18 \%$ for $\left[\mathrm{Cu}(\text { phen)(POP) }]^{+}, \quad 15 \%\right.$ for $[\mathrm{Cu}(\mathrm{dmp})(\mathrm{POP})]^{+}$and $26 \%$ for $\left.[\mathrm{Cu}(\mathrm{dpep})(\mathrm{POP})]^{+}\right) \cdot \cdot^{[5,8 \mathrm{cc}}$ These experimental observations are rationalized by the influence of the 2 and 9 substituents of the phenanthroline ligand on the geometric distortions that occur upon light excitation. In the MLCT excited state, the metal center changes its formal oxidation state from copper(I) to copper(II) and tends to adopt a more flattened coordination geometry that favors non-radiative deactivation processes involving binding of solvent molecules or counteranions to generate pentacoordinated exciplex species. ${ }^{[1,7]}$ This effect is limited by bulky substituents at the 2 and 9 positions of the phenanthroline moiety thus explaining the difference in emission quantum yields when going from $[\mathrm{Cu}(\text { phen })(\mathrm{POP})]^{+}$to $[\mathrm{Cu}(\mathrm{dmp})(\mathrm{POP})]^{+}$or $[\mathrm{Cu}(\mathrm{dpep})(\mathrm{POP})]^{+}$. It is therefore essential to develop new strategies to further stabilize $[\mathrm{Cu}(\mathrm{NN})(\mathrm{PP})]^{+}$complexes prepared from NN ligands bearing bulky substituents at the $\alpha$ positions of the coordinating $\mathrm{N}$ atoms to generate stable compounds with high emission quantum yields.

\section{Topological constraints to stabilize $[\mathrm{Cu}(\mathrm{NN})(\mathrm{PP})]^{+}$complexes}

A very efficient strategy to control the coordination of two distinct ligands around a copper $(\mathrm{I})$ cation is based on the combination of a macrocyclic chelating ligand $(\mathrm{L})$ with an acyclic chelating one (L') (Figure 2). ${ }^{[23-24]}$ Topological constraints resulting from the macrocyclic nature of $L$ prevent the formation of the homoleptic complex assembling two $L$ ligands around a tetracoordinated copper $(\mathrm{I})$ cation $\left(\left[\mathrm{Cu}(\mathrm{L})_{2}\right]^{+}\right)$. As a result, formation of the homoleptic complex $\left[\mathrm{Cu}\left(\mathrm{L}^{\prime}\right)_{2}\right]^{+}$would generate a frustrated metal ligand assembly for the macrocyclic ligand, which is highly unfavorable from a thermodynamic point of view. In contrast, all the ligands and metal binding sites are utilized when the heteroleptic complex $\left[\mathrm{Cu}(\mathrm{L})\left(\mathrm{L}^{\prime}\right)\right]^{+}$is formed. The perfect match between the number of ligands and the coordination number of the copper(I) cation generates only coordinatively saturated copper(I) complexes. According to the maximum site occupancy principle, ${ }^{[24-25]}$ the heteroleptic complexation scenario is largely more favorable. As a result, the dynamic coordination equilibrium is totally displaced in favor of the formation of $\left[\mathrm{Cu}(\mathrm{L})\left(\mathrm{L}^{\prime}\right)\right]^{+}$.

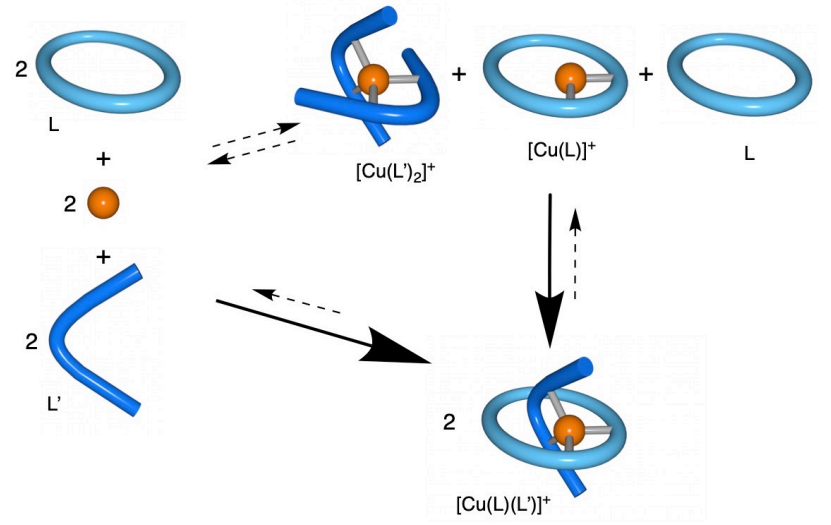

Figure 2. Control of the thermodynamic heteroleptic complexation scenario based on topological constraints. Starting from an equimolar mixture of a macrocyclic chelating ligand $L$ (pale blue), an acyclic chelating ligand L' (blue) and a copper(I) cation (orange), the formation of heteroleptic complex $\left[\mathrm{Cu}(\mathrm{L})\left(\mathrm{L}^{\prime}\right)\right]^{+}$is favoured as all the ligands are utilized to generate coordinatively saturated copper(I) complexes. Formation of the homoleptic complex $\left[\mathrm{Cu}\left(\mathrm{L}^{\prime}\right)_{2}\right]^{+}$ is disfavoured as it would generate a frustrated metal ligand assembly for the other ligand.

The strategy based on topological constraints initially developed by Sauvage and co-workers has been widely exploited to generate pseudo-rotaxane building blocks allowing the synthesis of sophisticated mechanically interlocked molecules and molecular machines. ${ }^{[26]}$ We have recently shown that this principle is also perfectly suited to stabilize heteroleptic complexes prepared from various PP ligands and macrocyclic phenanthroline derivatives. ${ }^{[15-17]}$ The preparation of the copper(I) pseudo-rotaxanes is depicted in Scheme 2. Macrocyclic phenanthroline ligands with ring sizes ranging from 30 to 42 atoms have been used as starting materials. $\left[\mathrm{Cu}\left(\mathrm{CH}_{3} \mathrm{CN}\right)_{4}\right] \mathrm{BF}_{4}$ (1 equiv.) and the appropriate PP ligand (1 equiv.) have been successively added to a solution of the macrocyclic NN ligand (1 equiv.). The copper(I) complexed pseudo-rotaxanes have then been obtained pure by recrystallization. Their structure has been confirmed by electrospray mass spectrometry as well as by their ${ }^{1} \mathrm{H},{ }^{13} \mathrm{C}$ and ${ }^{31} \mathrm{P}$ NMR spectra. Typical examples of X-ray crystal structures of copper(I) complexed pseudo-rotaxanes are shown in Figure 3. These heteroleptic complexes are remarkably stable in solution and no detectable ligand exchange reactions could be observed. When compared to the $[\mathrm{Cu}(\mathrm{NN})(\mathrm{PP})]^{+}$complexes prepared from the corresponding acyclic NN ligands (dmp or dpep, see Figure 2), the results obtained with the macrocyclic 
phenanthrolines are dramatically different, particularly when dppe or dppp have been used as the PP ligand. This observation clearly highlights the influence of the macrocyclic structure of the NN ligand on the stability of the heteroleptic $[\mathrm{Cu}(\mathrm{NN})(\mathrm{PP})]^{+}$complexes.

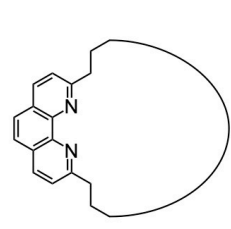

$\mathrm{m} 30, \mathrm{~m} 37$ or $\mathrm{m} 42$

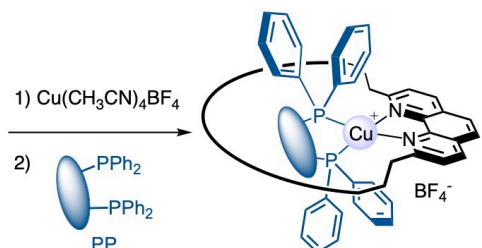

$[\mathrm{Cu}(\mathrm{m} 30)(\mathrm{PP})] \mathrm{BF}_{4}(\mathrm{PP}=$ dppe or $\mathrm{POP})$ $[\mathrm{Cu}(\mathrm{m} 37)(\mathrm{PP})] \mathrm{BF}_{4}(\mathrm{PP}=$ dppe, dppp or $\mathrm{POP})$ $[\mathrm{Cu}(\mathrm{m} 42)(\mathrm{PP})] \mathrm{BF}_{4}(\mathrm{PP}=\mathrm{POP})$

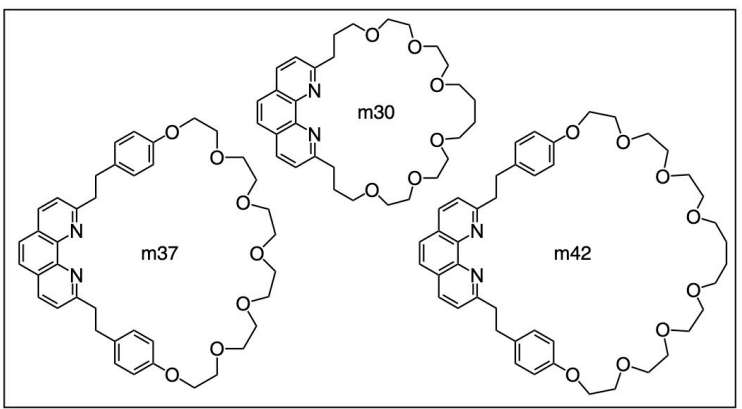

Scheme 2. Preparation of copper(I) pseudo-rotaxanes from macrocyclic phenanthrolines and PP ligands. Inset: structure of $\mathrm{m} 30, \mathrm{~m} 37$ and $\mathrm{m} 42$ (the number correspond to the ring size of the macrocycle).
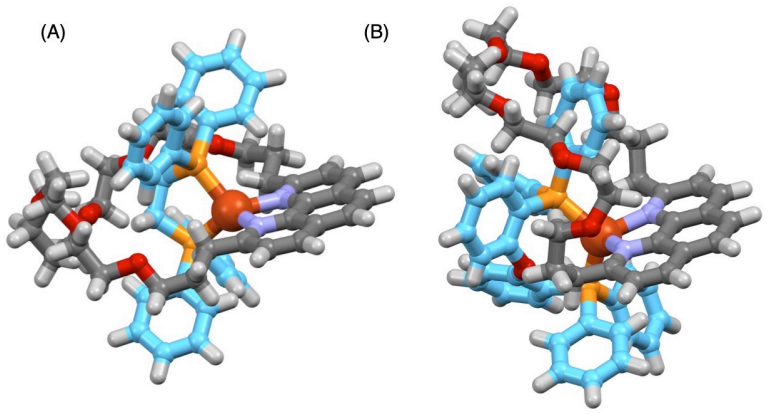

Figure 3. X-ray crystal structures of $\left[\mathrm{Cu}(\mathrm{m} 30)\left(\mathrm{dppe}^{2}\right) \mathrm{BF}_{4} \quad(\mathrm{~A})\right.$ and $\left[\mathrm{Cu}(\mathrm{m} 30)(\mathrm{POP}) \mathrm{BF}_{4}(\mathrm{~B})\right.$. The counteranion is omitted for clarity (Cu: dark orange, $\mathrm{P}$ : orange, $\mathrm{H}$ : white, $\mathrm{N}$ : blue, $\mathrm{C}$ : pale blue for the $\mathrm{PP}$ ligand and gray for macrocyclic NN ligand). Adapted from Ref. 16.

In the case of $[\mathrm{Cu}(\mathrm{m} 30)(\mathrm{POP})]^{+}$, detailed NMR investigations further supported by computational studies revealed particularly original dynamic molecular motions resulting from the folding/unfolding of the $\mathrm{m} 30$ macrocycle. ${ }^{[16]}$ The chain of the $\mathrm{m} 30$ ligand is flexible enough to allow a fast dynamic exchange between different conformers in solution (Figure 4). The $C_{2 v}$ symmetrical conformer (T1) in which the POP ligand is fully threaded through the macrocycle is destabilized by steric congestion due to the presence of the large phenyloxyphenyl bridging unit of the POP ligand within the cavity of macrocycle m30. Indeed, the macrocycle preferentially adopts a folded conformation (conformer T2) in order to minimize steric congestion as observed in the solid state (Figure 3B). These particular conformers in equilibrium have been named topomers ${ }^{[16]}$ by analogy to the dynamics of protein conformations in which a topomeric set of structures is obtainable through local backbone folding transformations. ${ }^{[27]}$
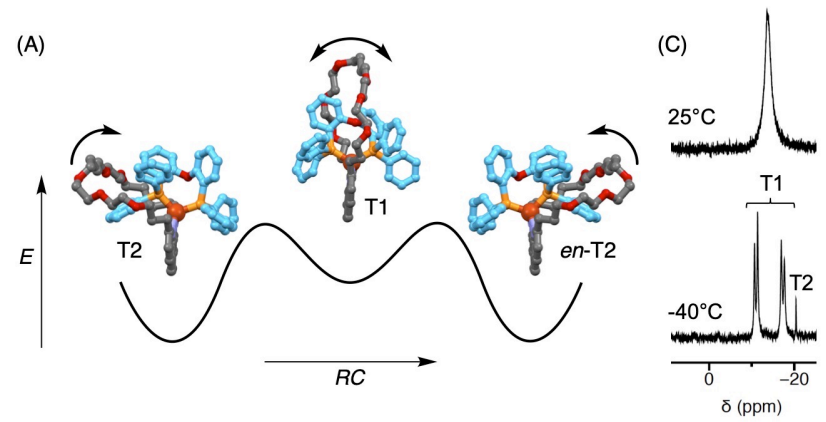

(B)

(D)
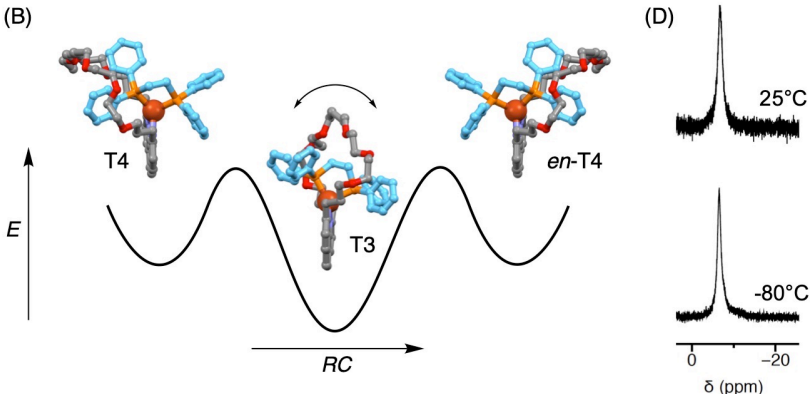

Figure 4. (A) Potential energy diagram proposed to explain the dynamic conformational exchange between the different topomers of $[\mathrm{Cu}(\mathrm{m} 30)(\mathrm{POP})] \mathrm{BF}_{4}$ deduced from variable temperature NMR studies. (B) In the case of $\left[\mathrm{Cu}(\mathrm{m} 30)(\mathrm{dppe}) \mathrm{BF}_{4}\right.$, the $C_{2 v}$ symmetrical topomer (T3) is largely preferred and the partially threated one (T4 and its enantiomer en-T4) could not be detected. ${ }^{31} \mathrm{P}$ NMR spectra $\left(\mathrm{CD}_{2} \mathrm{Cl}_{2}, 162 \mathrm{MHz}\right)$ of $[\mathrm{Cu}(\mathrm{m} 30)(\mathrm{POP})] \mathrm{BF}_{4}$ (C) and $[\mathrm{Cu}(\mathrm{m} 30)(\mathrm{dppe})] \mathrm{BF}_{4}(\mathrm{D})$ recorded at different temperature. Adapted from Ref. 16.

At $-40^{\circ} \mathrm{C}$, the dynamic exchange between the different topomers, i.e. topomerization, is slower than the NMR timescale and diagnostic signals corresponding to both topomers are detected in the ${ }^{31} \mathrm{P}$ NMR spectrum (Figure $4 \mathrm{C}$ ). The most stable topomer (T2) is largely major in solution under these conditions. The free energy of activation $\Delta G^{\ddagger}$ for the exchange between $\mathrm{T} 1$ and $\mathrm{T} 2$ is quite low $(12 \mathrm{kcal} / \mathrm{mol})$ and fast dynamic interconversion is observed at room temperature. In this way, each of the four peripheral phenyl rings of the POP ligand is alternatively located outside or inside the cavity of macrocycle $\mathrm{m} 30$, and the exchange takes place through the less energetically favored conformer T1. It can be noted that conformer T2 is chiral and the dynamic folding/unfolding of $\mathrm{m} 30$ is responsible for a dynamic 
racemization, i.e. fast exchange between $\mathrm{T} 2$ and en-T2 (Figure $4 \mathrm{~A})$.

Variable temperature NMR studies were also carried out with $[\mathrm{Cu}(\mathrm{m} 30)(\mathrm{dppe})]^{+}$. As shown in Figure 4B, the $\mathrm{C}_{2 v}$ symmetrical conformer (T3) is this time largely preferred. Folded topomer T4 could not be detected in the ${ }^{31} \mathrm{P}$ NMR spectra recorded at low temperature (Figure 4D). These observations are consistent with the conformation adopted by $[\mathrm{Cu}(\mathrm{m} 30)(\mathrm{dppe})]^{+}$in the solid state, the two $\mathrm{PPh}_{2}$ moieties being effectively located at opposite sides of the mean plane of the m30 macrocycle (Figure $3 \mathrm{~A}$ ). When compared to POP, the bridging unit of dppe is smaller and does not generate particular steric congestion. There is a clear energy penalty for the folding of $\mathrm{m} 30$, the fact that topomer $\mathrm{T} 2$ is favored shows that steric congestions must be relatively important for $[\mathrm{Cu}(\mathrm{m} 30)(\mathrm{POP})]^{+}$to almost totally displace the dynamic conformational equilibrium towards the partially threaded situation (T2). Despite increased ring sizes, a similar conformational equilibrium has been also observed for $[\mathrm{Cu}(\mathrm{m} 37)(\mathrm{POP})]^{+}$and $[\mathrm{Cu}(\mathrm{m} 42)(\mathrm{POP})]^{+}$. In both cases, the dynamic conformational equilibrium is in favor of a $\mathrm{C}_{1-}$ symmetrical conformer but the $\Delta G^{\ddagger}$ values estimated from the NMR data are decreased (m37: $9.3 \mathrm{kcal} / \mathrm{mol}$, and $\mathrm{m} 42: 8.6$ $\mathrm{kcal} / \mathrm{mol}){ }^{[17]}$

\section{Combining topological and steric constraints}

Incorporation of the phenanthroline chelating unit in a macrocyclic structure is an efficient strategy to stabilize $[\mathrm{Cu}(\mathrm{NN})(\mathrm{PP})] \mathrm{BF}_{4}$ derivatives as long as the macrocycle is large and flexible enough to allow the threading of the bulky $\mathrm{PPh}_{2}$ subunits of the PP ligand. The complexation scenario is however totally different when threading of the PP ligand is not possible anymore. This is the case when a more rigid macrocycle (M30) is used as the starting material (Scheme 3). ${ }^{[18]}$

$[\mathrm{Cu}(\mathrm{M} 30)(\mathrm{POP})] \mathrm{BF}_{4}$ was prepared by reaction of $\mathrm{M} 30$ with $\left[\mathrm{Cu}\left(\mathrm{CH}_{3} \mathrm{CN}\right)_{4}\right] \mathrm{BF}_{4}$ and POP. Crystals suitable for X-ray crystal structure analysis were obtained and the structure of $[\mathrm{Cu}(\mathrm{M} 30)(\mathrm{POP})] \mathrm{BF}_{4}$ is shown in Figure 5 . As observed for $[\mathrm{Cu}(\mathrm{m} 30)(\mathrm{POP})] \mathrm{BF}_{4}$ (Figure $\left.3 \mathrm{~B}\right)$, the POP ligand is only partially threaded through the macrocyclic ligand. M30 adopts a baskettype conformation to accommodate one phenyl moiety of the POP subunit, all the other aromatic subunits of the POP ligand being located on one side of the mean plane of the M30 macrocycle. The POP ligand is a chelating ligand by nature and the system is forced to adopt a sterically congested structure with a highly distorted tetrahedral coordination geometry around the copper(I) cation (Figure 5B). The rigid 2,9-diphenyl-1,10phenanthroline subunit of $M 30$ prevents the folding of the macrocyclic ligand allowing to properly coordinate the copper(I) cation as observed in the case of $[\mathrm{Cu}(\mathrm{m} 30)(\mathrm{POP})] \mathrm{BF}_{4}$ (Figure 2$)$. As a result, $[\mathrm{Cu}(\mathrm{M} 30)(\mathrm{POP})] \mathrm{BF}_{4}$ is not a very stable compound. Slow decomposition was effectively observed both in solution and in the solid state. It is also worth mentioning that any attempts to force the threading of the $\mathrm{PPh}_{2}$ moiety through the 30-membered ring of $\mathrm{M} 30$ by refluxing solutions of $[\mathrm{Cu}(\mathrm{M} 30)(\mathrm{POP})] \mathrm{BF}_{4}$ in high boiling point solvents failed to generate a $C_{2 v}$-symmetrical pseudo-rotaxane. Obviously, the $\mathrm{PPh}_{2}$ subunits of POP are too bulky to pass through the M30 macrocycle during the coordination process and the POP ligand is unable to adapt his behavior to this additional steric constraint. By contrast, dppp undergoes both steric and topological constraints, ${ }^{[28]}$ and adopts a non-chelating coordination mode to generate $\left[\mathrm{Cu}_{2}(\mathrm{M} 30)_{2}(\mu-\mathrm{dppp})\right]\left(\mathrm{BF}_{4}\right)_{2}($ Scheme 3$)$.

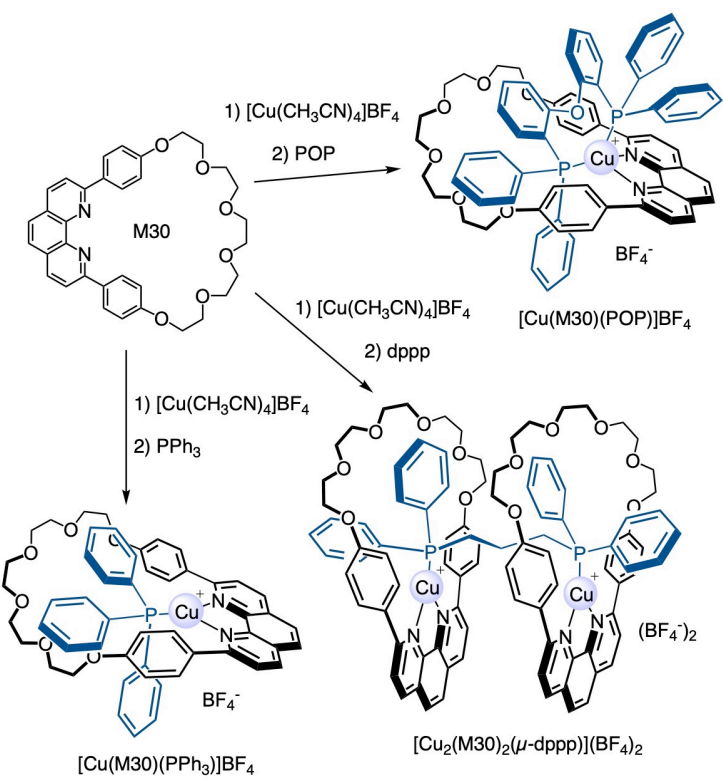

Scheme 3. Preparation of heteroleptic copper(I) complexes from M30 and phosphine ligands.

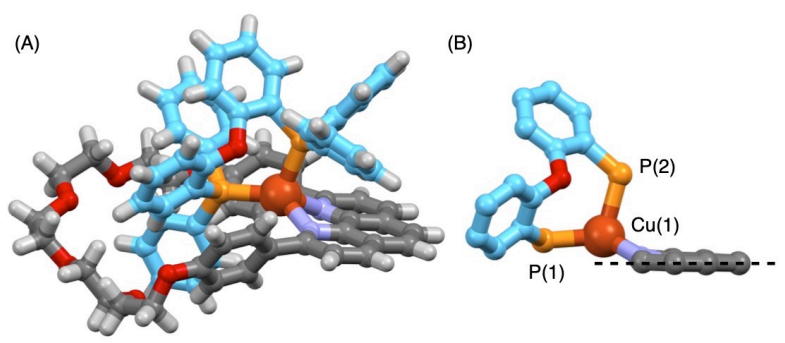

Figure 5. (A) X-ray crystal structure of $[\mathrm{Cu}(\mathrm{M} 30)(\mathrm{POP})] \mathrm{BF}_{4}$. The counteranion is omitted for clarity ( $\mathrm{Cu}$ : dark orange, $\mathrm{P}$ : orange, $\mathrm{H}$ : white, $\mathrm{N}$ : blue, $\mathrm{C}$ : pale blue for the PP ligand and gray for macrocyclic NN ligand). (B) Details of the coordination sphere around the copper(I) cation showing that the $\mathrm{Cu}(1)$ atom is located $0.737 \AA$ over the mean plane of the phenanthroline moiety, selected bond distances: $\mathrm{Cu}(1)-\mathrm{P}(1)$ : 2.265(2), $\mathrm{Cu}(1)-\mathrm{P}(2)$ : 2.394(3) A. Adapted from Ref. 18.

Indeed, the most efficient way for the system to fulfill the maximum occupancy principle is to adopt a dynamic heteroleptic complexation scenario in which the copper(I) cations are in a trigonal coordination geometry. In this way, all the ligands are coordinated and all the metals are utilized to form trigonal complexes. When the reaction is performed under stoichiometric 
conditions, a perfect match between the coordination number of the copper(I) cations and the number of ligands allows the formation of $\left[\mathrm{Cu}_{2}(\mathrm{M} 30)_{2}(\mu-\mathrm{dppp})\right]\left(\mathrm{BF}_{4}\right)_{2}$ in a quantitative yield. The ability of $\mathrm{M} 30$ to generate stable trigonal copper(I) complexes was further confirmed by the quantitative formation of $\left[\mathrm{Cu}(\mathrm{M} 30)\left(\mathrm{PPh}_{3}\right)\right] \mathrm{BF}_{4}$ starting from an equimolar mixture of $\mathrm{M} 30$, $\mathrm{PPh}_{3}$ and $\left[\mathrm{Cu}\left(\mathrm{CH}_{3} \mathrm{CN}\right)_{4}\right] \mathrm{BF}_{4}$ (Scheme 3 ). It is worth highlighting that the addition of $\mathrm{PPh}_{3}$ (1 equiv.) to a solution of $\left[\mathrm{Cu}(\mathrm{M} 30)\left(\mathrm{PPh}_{3}\right)\right] \mathrm{BF}_{4}$ led to a dynamic mixture of copper(I) complexes together with uncomplexed M30. Steric effects clearly prevents the formation of the tetracoordinated copper(I) complex $\left[\mathrm{Cu}(\mathrm{M} 30)\left(\mathrm{PPh}_{3}\right)_{2}\right] \mathrm{BF}_{4}$. The structure of the M30 ligand including a rigid 2,9-diphenyl-1,10-phenanthroline moiety is actually critical for the stabilization of trigonal copper(I) complexes such as $\left[\mathrm{Cu}(\mathrm{M} 30)\left(\mathrm{PPh}_{3}\right)\right] \mathrm{BF}_{4}$ and $\left[\mathrm{Cu}_{2}(\mathrm{M} 30)_{2}(\mu-\right.$ $\mathrm{dppp})]\left(\mathrm{BF}_{4}\right)_{2}$. These heteroleptic complexes with unprecedented structural features ${ }^{[29]}$ are stable both in solution and in the solid state, the copper(I) cations being well protected by the presence of the phenyl subunits of both the $P$ ligand and the M30. The trigonal coordination also prevents negative steric congestion leading to the destabilization of the system as observed in the case of $[\mathrm{Cu}(\mathrm{M} 30)(\mathrm{POP})] \mathrm{BF}_{4}$.

\section{Conclusion}

Macrocyclic phenanthroline derivatives are ideal ligands for the preparation of stable $[\mathrm{Cu}(\mathrm{NN})(\mathrm{PP})]^{+}$complexes. By preventing the formation of homoleptic bis-phenanthroline complexes, topological constraints are at the origin of a perfect control of the heteroleptic coordination scenario. The electronic properties of the copper(I)-complexed pseudo-rotaxanes constructed following this principle have not been discussed in the present concept article mainly focused on the coordination chemistry aspects. It must be however mentioned here that the pseudorotaxane structure positively impacts the excited-state properties of $[\mathrm{Cu}(\mathrm{NN})(\mathrm{PP})]^{+}$complexes and enhances their stability in light emitting devices. ${ }^{[17]}$ This design principle has been therefore already successfully used to generate stable copper(I) complexes for optoelectronic applications. On the other hand, combining topological and steric constraints allowed us to stabilize unprecedented tricoordinated heteroleptic copper(I) complexes. Investigations of the electronic properties of the first members of this family already revealed an interesting potential for optoelectronic applications. ${ }^{[18]}$ Overall, appropriate ligand design is critical for the preparation of stable copper(I) photosensitizers and the construction principles described herein provides important guidelines for future developments in the field of luminescent copper(I) complexes.

\section{Acknowledgements}

This research was supported by the University of Strasbourg, the CNRS, the International Center for Frontier Research in Chemistry and the LabEx Chimie des systèmes complexes. We would like to warmly thank all our co-workers for their outstanding contributions, their names are cited in the references. We further thank Jean-Pierre Sauvage and Nicola Armaroli for helpful discussions.

Keywords: Bis-phosphine ligands • copper • macrocycles • phenanthroline ligands $•$ Pseudo-rotaxanes

[1] (a) N. Armaroli, G. Accorsi, F. Cardinali, A. Listorti, Top. Curr. Chem. 2007, 280, 69-115. (b) A. Lavie-Cambot, M. Cantuel, Y. Leydet, G. Jonusauskas, D. M. Bassani, N. D. McClenaghan, Coord. Chem. Rev. 2008, 252, 2572-2584. (c) M. Nishikawa, S. Kume, H. Nishihara, Phys. Chem. Chem. Phys. 2013, 15, 10549-10565. (d) M. S. Lazorski, F. N. Castellano, Polyhedron 2014, 82, 57-70. (e) M. Iwamura, S. Takeuchi, T. Tahara, Acc. Chem. Res. 2015, 48, 782-791. (f) M. W. Mara, K. A Fransted, L. X. Chen, Coord. Chem. Rev. 2015, 282-283, 2-18.

[2] (a) M. Wallesch, D. Volz, D. M. Zink, U. Schepers, M. Nieger, T. Baumann, S. Bräse, Chem. Eur. J. 2014, 20, 6578-6590. (b) F. Dumur, Org. Electronics 2015, 21, 27-39.

[3] (a) B. Bozic-Weber, E. C. Constable, C. E. Housecroft, Coord. Chem Rev. 2013, 257, 3089-3106. (b) C. E. Housecroft, E. C. Constable, Chem. Soc. Rev. 2015, 44, 8386-8398. (c) M. Sandroni, Y. Pellegrin, F. Odobel, C. R. Chimie 2016, 19, 79-93.

[4] (a) O. Reiser, Acc. Chem. Res. 2016, 49, 1990-1996. (b) A. C. Hernandez-Perez, S. K. Collins, Acc. Chem. Res. 2016, 49, 1557-1565. (c) Y. Zhang, M. Schulz, M. Wächltler, M. Karnahl, B. Dietzek, Coord. Chem. Rev. 2018, 356, 127-146. (d) L. Buzzetti, G. E. M. Crisenza, P. Melchiorre, Angew. Chem. Int. Ed., DOI : 10.1002/anie.201809984

[5] D. G. Cuttell, S.-M. Kuang, P. E. Fanwick, D. R. McMillin, R. A. Walton, J. Am. Chem. Soc. 2002, 124, 6-7.

[6] S.-M. Kuang, D. G. Cuttell, D. R. McMillin, P. E. Fanwick, R. A. Walton Inorg. Chem. 2002, 41, 3313-3322.

[7] For photophysical investigations on [Cu(NN)(PP)] $]^{+}$complexes, see: (a) P. Coppens, I. I. Vorontsov, T. Graber, A. Y. Kovalevsky, Y.-S. Chen, G. Wu, M. Gembicky, I. V. Novozhilova, J. Am. Chem. Soc. 2004, 126, 5980-5981. (b) A. Listorti, G. Accorsi, Y. Rio, N. Armaroli, O. Moudam, A. Gégout, B. Delavaux-Nicot, M. Holler, J.-F. Nierengarten, Inorg. Chem 2008, 47, 6254-6261. (c) R. Czerwieniec, J. Yu, H. Yersin, Inorg. Chem. 2011, 50, 8293. C. L. Linfoot, M. J. Leitl, P. Richardson, A. F. Rausch, O. Chepelin, F. J. White, H. Yersin, N. Robertson, Inorg. Chem. 2014, 53, 10854-10861. (d) M. Nishikawa, S. Sawamura, A. Haraguchi, J. Morikubo, K. Takao, T. Tsubomura, Dalton Trans. 2015, 44, 411-418. (e) R. Czerwieniec, H. Yersin, Inorg. Chem. 2015, 54, 4322-4327. (f) L. Bergmann, G. J. Hedley, T. Baumann, S. Bräse, I. D. W. Samuel, Sci. Adv. 2016, 2, e1500889. (g) Y. Sun, V. Lemaur, J. I. Beltrán, J. Cornil, J. Huang, J. Zhu, Y. Wang, R. Fröhlich, H. Wang, L. Jiang, G. Zou, Inorg. Chem. 2016, 55, 5845-5852. (h) M. Washimi, M. Nishikawa, N. Shimoda, S. Satokawa, T. Tsubomura, Inorg. Chem. Front. 2017, 4, 639-649. (i) D. Moonshiram, P. G. Barros, C. G. Suriñach, A. Picón, C. Liu, X. Zhang, M. Karnahl, A. Llobet, Chem. Eur. J. 2018, 24, 64646472. (j) E. Leoni, J. Mohanraj, M. Holler, M. Mohankumar, I. Nierengarten, F. Monti, A. Sournia-Saquet, B. Delavaux-Nicot, J.-F. Nierengarten, N. Armaroli, Inorg. Chem., DOI: 10.1021/acs.inorgchem.8b02879.

[8] For light emitting devices prepared from $[\mathrm{Cu}(\mathrm{NN})(\mathrm{PP})]^{+}$complexes, see: (a) Q. Zhang, Q. Zhou, Y. Cheng, L. Wang, D. Ma, X. Jing, F. Wang, Adv. Mater. 2004, 16, 432-436. (b) Q. Zhang, Q. Zhou, Y. Cheng, L. Wang, D. Ma, X. Jing, F. Wang, Adv. Funct. Mater. 2006, 16, 12031208. (c) N. Armaroli, G. Accorsi, M. Holler, O. Moudam, J.-F. Nierengarten, Z. Zhou, R. T. Wegh, R. Welter, Adv. Mater. 2006, 18, 1313-1316. (d) T. MacCormick, W.-L. Jia, S. Wang, Inorg. Chem. 2006, 45, 147-155. (e) R. D. Costa, D. Tordera, E. Orti, H. Bolink, J. Schönle, S. Graber, C. E. Housecroft, E. C. Constable, J. A. Zampese, J. Mater. Chem. 2011, 21, 16108-16118. (f) L. Bergmann, J. Friedrichs, M. 
Mydlak, T. Baumann, M. Nieger, S. Bräse, Chem. Commun. 2013, 49 , 6501-6503. (g) D. Asil, J. A. Foster, A. Patra, X. de Hatten, J. del Barrio, O. A. Scherman, J. R. Nitschke, R. H. Friend, Angew. Chem. Int. Ed. 2014, 53, 8388-8391. (h) S. Keller, E. C. Constable, C. E. Housecroft, M. Neuburger, A. Prescimone, G. Longo, A. Pertegás, M. Sessolo, H. J. Bolink, Dalton Trans. 2014, 43, 16593-16596. (i) G. Cheng, G. K.-M. So W.-P. To, Y. Chen, C.-C. Kwok, C. Ma, X. Guan, X. Chang, W.-M. Kwok, C.-M. Che, Chem. Sci. 2015, 6, 4623-4635. (j) S. Keller, A. Pertegás, G. Longo, L. Martínez, J. Cerdá, J. M. Junquera-Hernández, A. Prescimone, E. C. Constable, C. E. Housecroft, E. Ortí, H. J. Bolink, J. Mater. Chem. C 2016, 4, 3857-3871. (k) F. Brunner, L. Martínez-Sarti, S. Keller, A. Pertegás, A. Prescimone, E. C. Constable, H. J. Bolink, C E. Housecroft, Dalton Trans. 2016, 45, 15180-15192. (I) F. Zhang, Y. Guan, X. Chen, S. Wang, D. Liang, Y. Feng, S. Chen, S. Li, Z. Li, F. Zhang, C. Lu, G. Cao, B. Zhai, Inorg. Chem. 2017, 56, 3742-3753. (m) G. K.-M. So, G. Cheng, J. Wang, X. Chang, C.-C. Kwok, H. Zhang, C.M. Che, Chem. Asian J. 2017, 12, 1490-1498. (n) S. Keller, F. Brunner, J. M. Junquera-Hernández, A. Pertegás, M. G. La Placa, A. Prescimone, E. C. Constable, H. J. Bolink, E. Ortí, C. E. Housecroft, ChemPlusChem 2018, 83, 217-219.

[9] For dye sensitized solar cells prepared from $[\mathrm{Cu}(\mathrm{NN})(\mathrm{PP})]^{+}$complexes, see: (a) C. L. Linfoot, P. Richardson, T. E. Hewat, O. Moudam, M. M. Forde, A. Collins, F. White, N. Robertson, Dalton Trans. 2010, 39 8945-8956. (b) M. Sandroni, M. Kayanuma, M. Rebarz, H. Akdas-Kilig, Y. Pellegrin, E. Blart, H. Le Bozec, C. Daniel, F. Odobel, Dalton Trans 2013, 42, 14628-14638.

[10] For electrochemical properties of $[\mathrm{Cu}(\mathrm{NN})(\mathrm{PP})]^{+}$complexes, see: (a) N. Armaroli, G. Accorsi, G. Bergamini, P. Ceroni, M. Holler, O. Moudam, C. Duhayon, B. Delavaux-Nicot, J.-F. Nierengarten, Inorg. Chim. Acta 2007, 360, 1032-1042. (b) M. Nishikawa, K. Nomoto, S. Kume, H. Nishihara, Inorg. Chem. 2013, 52, 369-380. (c) Y. Hattori, M. Nishikawa T. Kusamoto, S. Kume, H. Nishihara, Inorg. Chem. 2014, 53, 28312840.

[11] For applications of $[\mathrm{Cu}(\mathrm{NN})(\mathrm{PP})]^{+}$complexes in photocatalysis, see: (a) S.-P. Luo, E. Mejía, A. Friedrich, A. Pazidis, H. Junge, A.-E. Surkus, R. Jackstell, S. Denurra, S. Gladiali, S. Lochbrunner, M. Beller, Angew. Chem. Int. Ed. 2013, 52, 419-423. (b) M. Karnahl, E. Mejía, N. Rockstroh, S. Tschierlei, S.-P. Luo, K. Grabow, A. Kruth, V. Brüser, H. Junge, S. Lochbrunner, M. Beller, ChemCatChem 2013, 6, 82-86. (c) S Tschierlei, M. Karnahl, N. Rockstroh, H. Junge, M. Beller, S. Lochbrunner, ChemPhysChem 2014, 15, 3709-3713. (d) B. Wang, D. P. Shelar, X. Z. Han, T. T. Li, X. Guan, W. Lu, K. Liu, Y. Chen, W.-F. Fu, C.-M. Che, Chem. Eur. J. 2015, 21, 1184-1190. (e) A. J. J. Lennox, S Fischer, M. Jurrat, S.-P. Luo, N. Rockstroh, H. Junge, R. Ludwig, M Beller, Chem. Eur. J. 2016, 22, 1233-1238. (f) M. Heberle, S. Tschierlei, N. Rockstroh, M. Ringenberg, W. Frey, H. Junge, M. Beller, S. Lochbrunner, M. Karnahl, Chem. Eur. J. 2017, 23, 312-319. (g) J. Kim, D. R. Whang, S. Y. Park, ChemSusChem 2017, 10, 1883-1886. (h) A Rosas-Hernández, C. Steinlechner, H. Junge, M. Beller, Green Chem. 2017, 19, 2356-2360. (i) B. J. McCullough, B. J. Neyhouse, B. R. Schrage, D. T. Reed, A. J. Osinski, C. J. Ziegler, T. A. White, Inorg Chem. 2018, 57, 2865-2875. (j) Z. Xu, Y. Cao, B. O. Patrick, M. O. Wolf Chem. Eur. J. 2018, 24, 10315-10319. (k) K. Matsuo, E. Yamaguchi, A. Itoh, Asian J. Org. Chem. DOI: 10.1002/ajoc.201800533

[12] (a) S. Sakaki, G. Koga, K. Ohkubo, Inorg. Chem. 1986, 25, 2330-2333. (b) S. Sakaki, G. Koga, S. Hinokuma, S. Hashimoto, K. Ohkubo, Inorg Chem. 1987, 26, 1817-1819.

[13] (a) R. A. Rader; D. R. McMillin, M. T. Buckner, T. G. Matthews, D. J. Casadonte, R. K. Lengel, S. B. Whittaker, L. M. Darmon, F. E. Lytle, J. Am. Chem. Soc. 1981, 103, 5906-5912 (b) A. A. Del Paggio, D. R. McMillin, Inorg. Chem. 1983, 22, 691-692. (c) D. J. Casadonte, D. R McMillin, Inorg. Chem. 1987, 26, 3950-3952.

[14] A. Kaeser, M. Mohankumar, J. Mohanraj, F. Monti, M. Holler, J.-J. Cid, O. Moudam, I. Nierengarten, L. Karmazin-Brelot, C. Duhayon, B.
Delavaux-Nicot, N. Armaroli, J.-F. Nierengarten, Inorg. Chem. 2013, 52, 12140-12151.

[15] M. Mohankumar, M. Holler, J.-F. Nierengarten, J.-P. Sauvage, Chem Eur. J. 2012, 18, 12192-12195.

[16] M. Mohankumar, M. Holler, M. Schmitt, J.-P. Sauvage, J.-F. Nierengarten, Chem. Commun. 2013, 49, 1261-1263.

[17] M. Mohankumar, M. Holler, E. Meichsner, J.-F. Nierengarten, F. Niess, J.-P. Sauvage, B. Delavaux-Nicot, E. Leoni, F. Monti, J. M. Malicka, M Cocchi, E. Bandini, N. Armaroli, J. Am. Chem. Soc. 2018, 140, 23362347.

[18] M. Mohankumar, F. Monti, M. Holler, F. Niess, B. Delavaux-Nicot, N. Armaroli, J.-P. Sauvage, J.-F. Nierengarten, Chem. Eur. J. 2014, 20 12083-12090.

[19] (a) K. Saito, T. Arai, N. Takahashi, T. Tsukuda, T. Tsubomura, Dalton Trans. 2006, 4444-4448. (b) R. Czerwieniec, K. Kowalski, H. Yersin Dalton Trans. 2013, 42, 9826-9830. (c) T. Tsubomura, K. Kimura, M. Nishikawa, T. Tsukuda, Dalton Trans. 2015, 44, 7554-7562.

[20] (a) P. Comba, C. Katsichtis, B. Nuber, H. Pritzkow, Eur. J. Inorg. Chem. 1999, 777-783. (b) O. Moudam, A. Kaeser, B. Delavaux-Nicot, C. Duhayon, M. Holler, G. Accorsi, N. Armaroli, I. Séguy, J. Navarro, P. Destruel, J.-F. Nierengarten, Chem. Commun. 2007, 3077-3079.

[21] (a) B. R. James, R. J. P. Williams, J. Chem. Soc. 1961, 2007-2019. (b) F. A. Arnaud-Neu, E. Marques, M.-J. Schwing-Weill, C. O. DietrichBuchecker, J.-P. Sauvage, J. Weiss, New J. Chem. 1988, 12, 15-20.

[22] (a) R. Venkateswaran, M. S. Balakrishna, S. M. Mobin, H. M. Tuononen, Inorg. Chem. 2007, 46, 6535-6541. (b) J. Yuasa, M. Dan, T. Kawai, Dalton Trans. 2013, 42, 16096-16101. (c) A. Kaeser, O. Moudam, G Accorsi, I. Séguy, J. Navarro, A. Belbakra, C. Duhayon, N. Armaroli, B. Delavaux-Nicot, J.-F. Nierengarten, Eur. J. Inorg. Chem. 2014, 13451355.

[23] (a) C. O. Dietrich-Buchecker, J.-P. Sauvage, J.-P. Kintzinger, Tetrahedron Lett. 1983, 24, 5095-5098. (b) C. O. Dietrich-Buchecker, J.-P. Sauvage, Tetrahedron 1990, 46, 503-512.

[24] For a review on metal-coordination-driven dynamic heteroleptic architectures, see: S. De, K. Mahata, M. Schmittel, Chem. Soc. Rev. 2010, 39, 1555-1575.

[25] (a) R. Krämer, J.-M. Lehn, A.-M. Marquis-Rigault, Proc. Natl. Acad. Sci. USA 1993, 90, 5394-5398. (b) M. Albrecht, Chem. Rev. 2001, 101 3457-3498. (c) R. Chakrabarty, P. S. Mukherjee, P. J. Stang, Chem. Rev., 2011, 111, 6810-6918. (d) M. Fujita, Chem. Soc. Rev., 1998, 27 417-425.

[26] (a) J.-P. Sauvage, C. Dietrich-Buchecker (Eds.), Molecular Catenanes, Rotaxanes and Knots - A Journey Through the World of Molecular Topology, J. Wiley and Sons, 2008. (b) C. J. Bruns, J. F. Stoddart, The Nature of the Mechanical Bond - From Molecules to Machines, J. Wiley \& Sons, 2016.

[27] A. Debe, M. J. Carlson, W. A. Goddard III, Proc. Natl. Acad. Sci. U. S. A. 1999, 96, 2596-2601.

[28] Steric constraints have been used to prepare heteroleptic copper(I) complexes. In this case, the concept is based on the steric obstruction of homoleptic metal complexes by using the bulky 2,9-dimesityl-1,10phenanthroline ligand. Hence, in the presence of an unhindered counterpart, for example 1,10-phenanthroline, quantitative heteroleptic complex formation is exclusively observed. See: (a) M. Schmittel, A Ganz, Chem. Commun. 1997, 999-1000. (b) M. T. Miller, P. K. Gantzel, T. B. Karpishin, J. Am. Chem. Soc. 1999, 121, 4292-4293. (c) M Schmittel, A. Ganz, D. Fenske, Org. Lett. 2002, 4, 2289-2292. (d) M. Schmittel, H. Ammon, V. Kalsani, A. Wiegrefe, C. Michel, Chem. Commun. 2002, 2566-2567. (e) V. Kalsani, H. Amon, F. Jäckel, J. P. Rabe, M. Schmittel, Chem. Eur. J. 2004, 10, 5481-5492.

[29] Following our first report, related $[\mathrm{Cu}(\mathrm{NN})(\mathrm{PR} 3)]^{+}$derivatives obtained from acyclic phenanthrolines and phosphine ligands with bulky $R$ groups have been reported, see: D. Kakizoe, M. Nishikawa, Y. Fujii, T. Tsubomura, Dalton Trans. 2017, 46, 14804-14811. 


\section{Entry for the Table of Contents}

\section{CONCEPT}

Macrocyclic phenanthroline ligands have been used for the preparation of $[\mathrm{Cu}(\mathrm{NN})(\mathrm{PP})]^{+}$pseudo-rotaxanes. Topological constraint drives the thermodynamic equilibrium toward the exclusive formation of the heteroleptic complex as long as the macrocycle is large and flexible enough to allow the threading of the PP ligand. In contrast, when the threading is prevented by steric constraints, unprecedented copper(I) complexes are obtained.

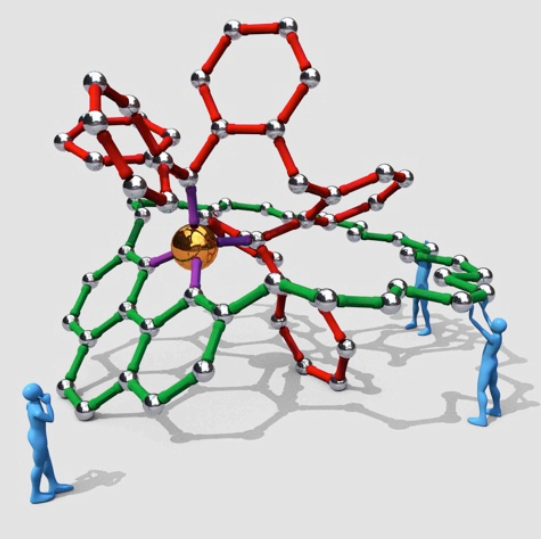

Michel Holler, Béatrice Delavaux-Nicot and Jean-François Nierengarten

Page No. - Page No.

Topological and steric constraints to stabilize heteroleptic copper(I) complexes combining phenanthroline ligands and phosphines 